\title{
Lightning protection of underground gas storages
}

\author{
V.N. Shuleikin \\ Oil and Gas Research Institute, Russian Academy of Sciences, Moscow \\ E-mail: shvn1947@yandex.ru
}

\begin{abstract}
According to the world statistics of thunderstorms, cloud-to-earth lightning discharges are most often observed in clay and humid areas, gentle river banks, and swampy areas where groundwater is the closest to the Earth's surface. Here, an increased discharge of radon and its carrier gases - hydrogen and methane - to the atmosphere takes place, which is noticeably enhanced by a prestorm pressure drop. Similar conditions are created during the injection of artificial gas storages on the territories of injection well clusters, where existing lightning conductors are unable to provide reliable protection against the cloud-to-earth discharges.
\end{abstract}

Keywords: hydrogen, methane, radon, atmospheric pressure, injection well clusters, lightning discharges.

Citation: Shuleikin V.N. Lightning protection of underground gas storages // Actual Problems of Oil and Gas. 2019. Iss. 3(26). https://doi.org/10.29222/ipng.2078-5712.2019-26.art15

\section{Introduction}

For many decades, the studies of atmospheric electricity have been separating the fair weather electricity and the thunderstorm electricity [1-6]. Traditionally, the «fair weather» term means a meteorological situation where in the absence of thunderstorms, any kind of precipitation, hoar frost, fog, dust, and low cloud, the wind speed is at most $6 \mathrm{~m} / \mathrm{s}$ [7-9]. Moreover, additional restrictions are imposed on significant concentrations of neutral condensation nuclei and powerful sources of ionization.

The planetary scale of the global electrical circuit [10] combines these two scientific directions. Thunderstorms will rattle and somewhere the fair weather conditions will be observed around the globe for the same time. In this case, both these processes will contribute to the phenomenon of the global electrical circuit. Let us consider some examples of experimental observations where in the areas with fair weather conditions, a transition to a thunderstorm activity is possible. Within the established relationships between hydrogen, methane and radon [11,12], we'll testify that due to local geological features, geodynamic and meteorological processes in large areas, conditions are created for the occurrence of cloud-to-ground discharges under abnormal concentrations of these gases. 


\section{Geology and thunderstorm activity}

In the early 1900s, Professor L.N. Bogoyavlensky associated the territorial recurrence of the cloud-to-earth lightning discharges with the radioactivity level. According to his statistics obtained for the region near Sestroretsk, the high radioactivity level (high air ionization level) has led to a high perishability this area from lightning discharges. This phenomenon was steadily observed by him each and every year. Unfortunately, the current condition of these territories is unknown. However, there is a unique Lake Lopukhinka near Sestroretsk formed by a number of springs, where the volumetric activity of radon reaches about $400 \mathrm{~Bq} / \mathrm{l}$. In the town Sestroretsk and Beloostrov and Pesochny settlements, Sestroretsk Swamp State Nature Reserve, the total area of 1,900 hectares, is located. In the western part of the swamp adjacent to the Sestroretsky Razliv Lake, the volumetric activity of radon reaches $252 \mathrm{~Bq} / \mathrm{l}$.

Following the results by L.N. Bogoyavlensky, the presence of granites, slates, and metal ores in the ground strongly changes local air ionization; the closer to the Earth's surface they occur, the higher ionization is. Territories of direct rocks exposure are three-fold more frequently struck by lightning than in the case of their occurrence at $\mathrm{f}$ depth of 60-80 m. For example, the Kursk Magnetic Anomaly suffers up to 32 thunderstorms and the Tikhvin Magnetic Anomaly up to 25 thunderstorms annually.

The statement by L.N. Bogoyavlensky regarding the increased air ionization - the increased thunderstorm activity in the areas of shales occurrence - is proved by data of the National Lightning Detection Network (NLDN, USA) - the largest network in North America. Fig. 1 shows thunderstorm foci registered by this network. The spotty structure of these foci location is obvious. This phenomenon allows saying that local geological and geodynamic features of the ground structure have an effect on territorial distribution of lightning discharges.

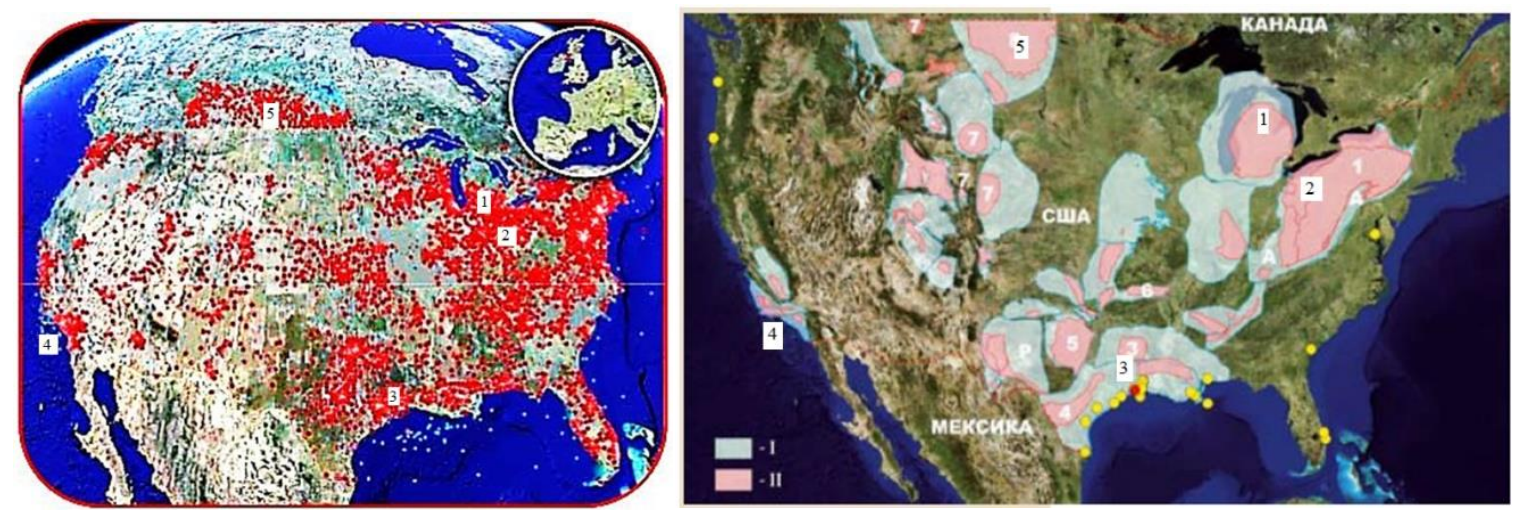

Fig. 1. The location of thunderstorm activity foci in North America according to NLDN - over 150,000 sensors (left), the map of shale gas deposits and development in North America (right) 
Compare the thunderstorm activity foci locations to the map of shale gas deposits and development (see Fig. 1, right). Numbers 1 to 5 on these maps indicate territories with coinciding areas of thunderstorm activity and shale gas development: 1 - Michigan (MI); 2 New York (NY) and Pennsylvania (PA); 3 - Texas (TX) and Louisiana (LA), the Gulf Coast; 4 California (CA), the southern coast of the Pacific Ocean; 5 - Montana (MT) and North Dakota (ND), Canadian border.

The shale gas developments are accompanied by excessive discharge of methane - the main shale gas component - to the surface atmosphere. Methane, in turn, transfers radon to the near-surface atmosphere.

To illustrate the increased air ionization above an ore body, we use the observation results of atmospheric electric field (AEF) above Novoselkovsk titanic iron-magnetite Ore Manifestation (Belarus) - Fig. 2 [12].

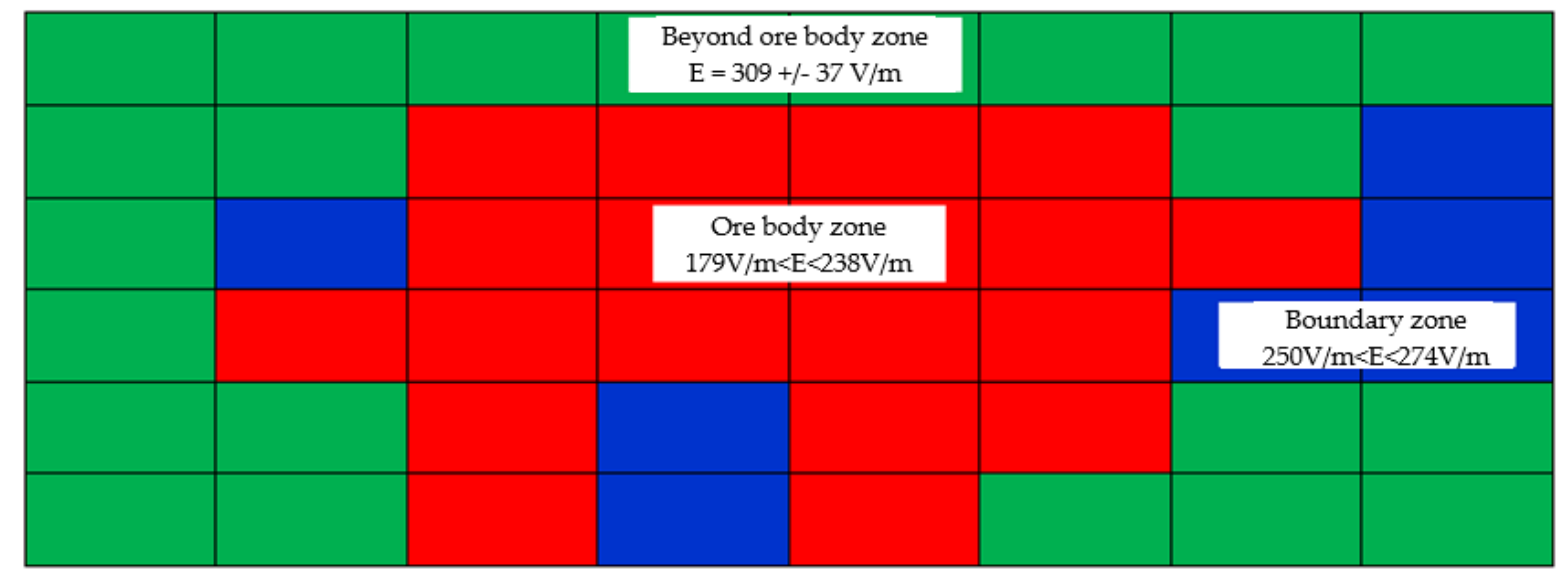

Fig. 2. The plan of equipotential zones above the Novoselkovsk titanic iron-magnetite Ore Manifestation plotted following the results of AEF observations performed on August 19-20, 1987

In the ore body projection area (the occurrence depth of about $200 \mathrm{~m}$ with a characteristic lateral dimension of about $400 \mathrm{~m}$ ), a dip of the atmospheric electric field is observed with confidence. The reason for field falloff detected is electrochemical processes in the ore body cap accompanied by the release of hydrogen - the main gas-carrier of radon - into the near-surface atmosphere $[11,12]$.

Statistically, lightning discharges most often hit clayey soil and wet areas, sloping river banks, and boggy territories, where groundwater closely approaches the ground surface. Swamps show the presence of biogenic methane, which is the second gas-carrier of radon; the 
argillaceous confining bed is also a stable source of ionizer, showing the maternal substance content twice as less as in granites [13].

Fig. 3 shows observation results on polar conductivities of atmospheric air in the marshy area of the profile. The criterion of a marshland is reed. The ratio of the average total polar conductivity in the marshy area of the profile ( $\lambda_{\text {marsh }}=0.89$ rel. units) to the mean value at pickets $14-19$ and $24-34(\lambda=0.42$ rel. units $)$ is $\lambda$ marsh $/ \lambda=2.1$. Low values of the total polar conductivity ratio are determined by a meteorological situation - measurements were carried out in the Stavropol Territory during a long-lasting abnormally hot weather of about $+40{ }^{\circ} \mathrm{C}$ during the day.

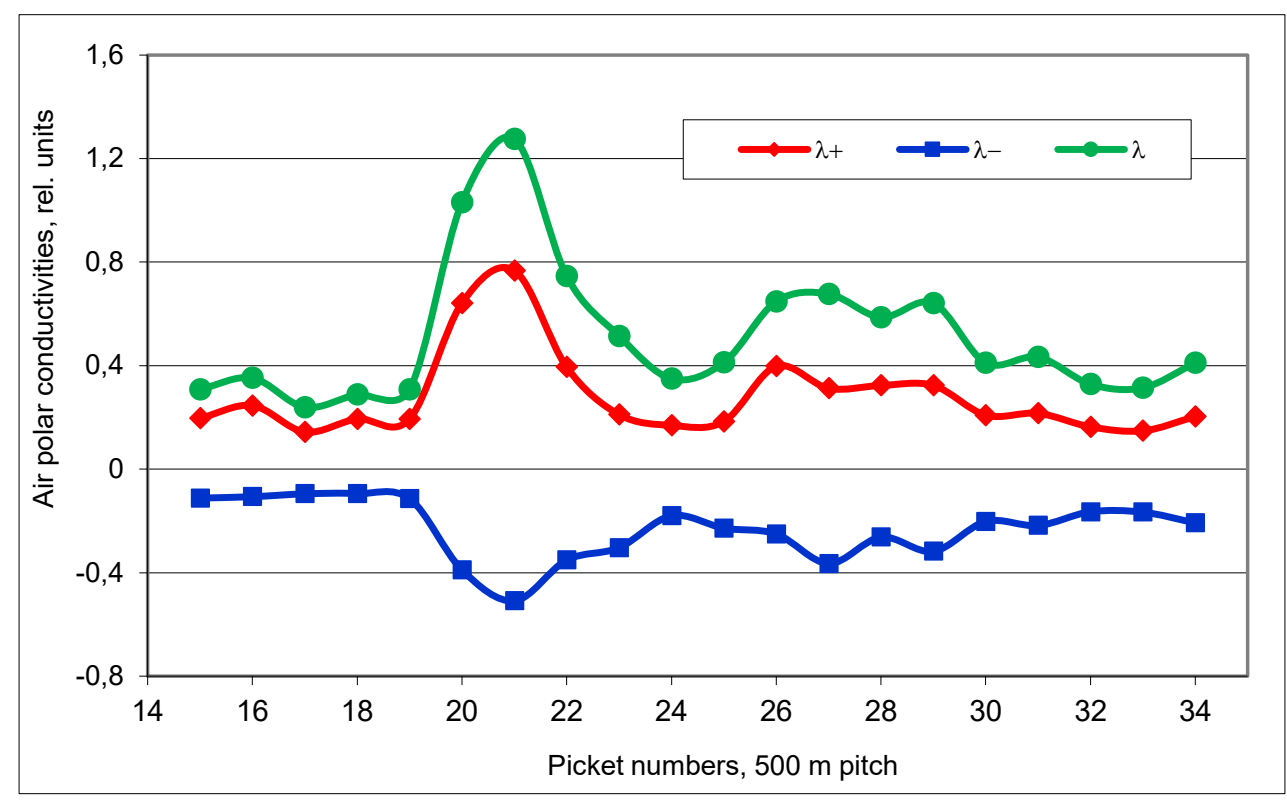

Fig. 3. Variations of the air polar conductivity on the profile of the North Stavropol underground gas storage; at the interval between pickets 20 and 23 , the profile crosses the marsh area

Fig. 4 illustrates the pronounced effect of ionization on the air conductivity as a result of the radionuclides release in the Chernobyl Nuclear Power Plant accident.

As far as is known, the Ostankino TV tower built on a boggy territory is the highest lightening conductor in Russia. Over the years, experts from Krzhizhanovsky Power Engineering Institute had been making photos of the Tower from several neighboring structures simultaneously and concluded that lightnings not always hit the top of the Ostankino Tower - there were also discharges to the base of the sightseeing platform and to the base of the Tower. Statistically, 5 to 7 percent of lightnings hit the lateral surface of the Tower far below its top. 


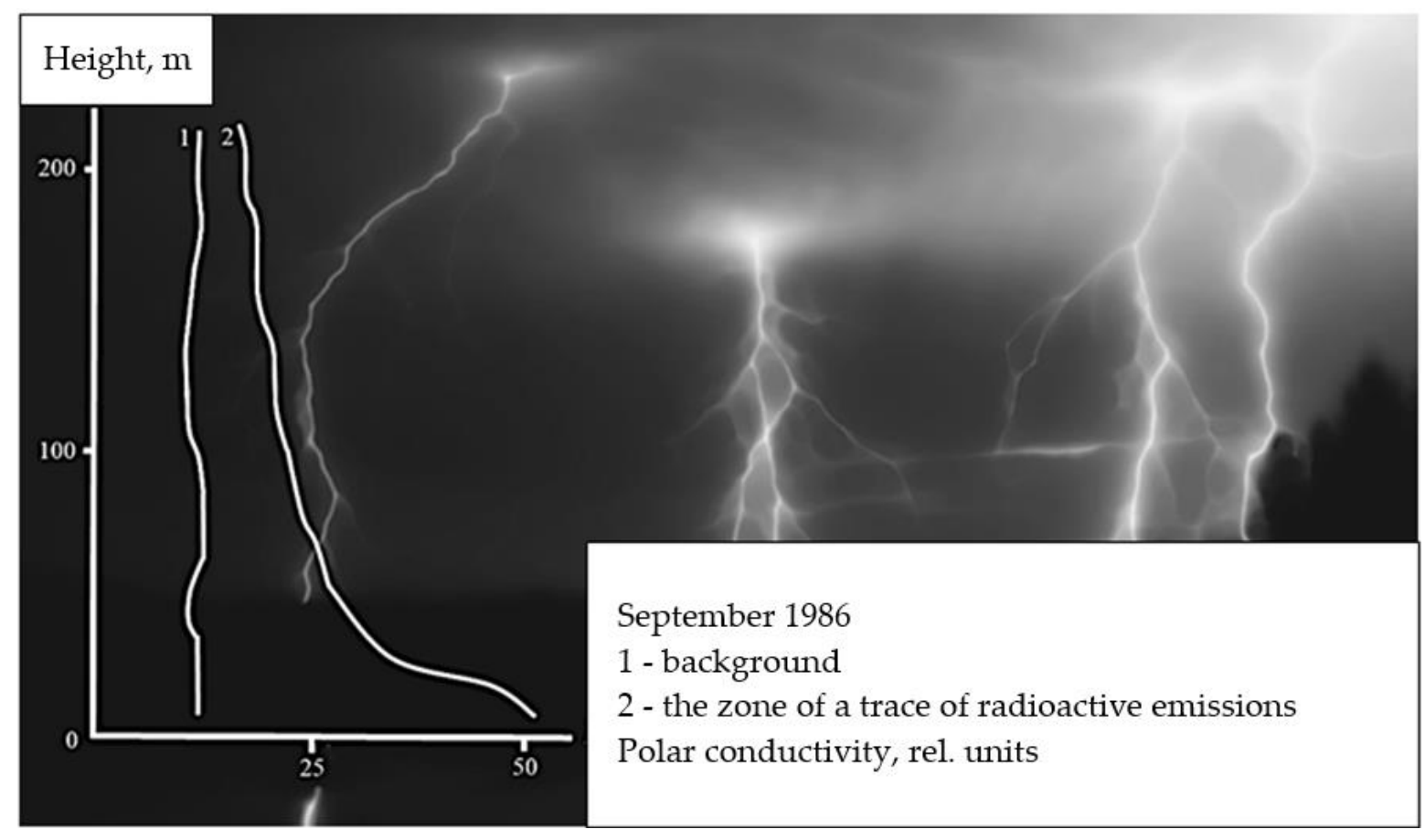

Fig. 4. Electrical state of the boundary atmospheric layer affected by the radioactive release in the Chernobyl NPP accident

Moreover, in the vicinity of the Ostankino Tower, downward lightnings hit the boggy area with the same frequency as before it was constructed. This allows assuming that excessive emission of biogenic methane (boggy areas) and, as a consequence, radon, in the prethunderstorm period due to a drop in atmospheric pressure increases conductive characteristics of the atmospheric surface layers.

\section{The effect of atmospheric pressure on the soil radon exhalation}

Formation of a cumulonimbus cloud is accompanied by a drop in atmospheric pressure. Under stable condition, the weight of the air column keeps aquifers at a certain level. A drop in atmospheric pressure leads to an increase in their levels: the sensitivity of groundwater and perch level to a drop in atmospheric pressure of about $8 \mathrm{~mm} / \mathrm{hPa}$; in water-bearing formations isolated from the atmosphere, it is significantly less than $2 \mathrm{~mm} / \mathrm{hPa}[14,15]$.

Verification of the hydrogeological regulation of electrical characteristics of the atmosphere with variations in atmospheric pressure was carried out in May 1987 on the Uznozh vibration test site (Belarus). Fig. 5 shows the record of measured air-to-ground current values, $j(t)$, and calculated current values as a function of water level variations in the observation well, $\mathrm{j}(\mathrm{z})$, when the atmospheric pressure drops before a thunderstorm, and its variations during drizzle. 


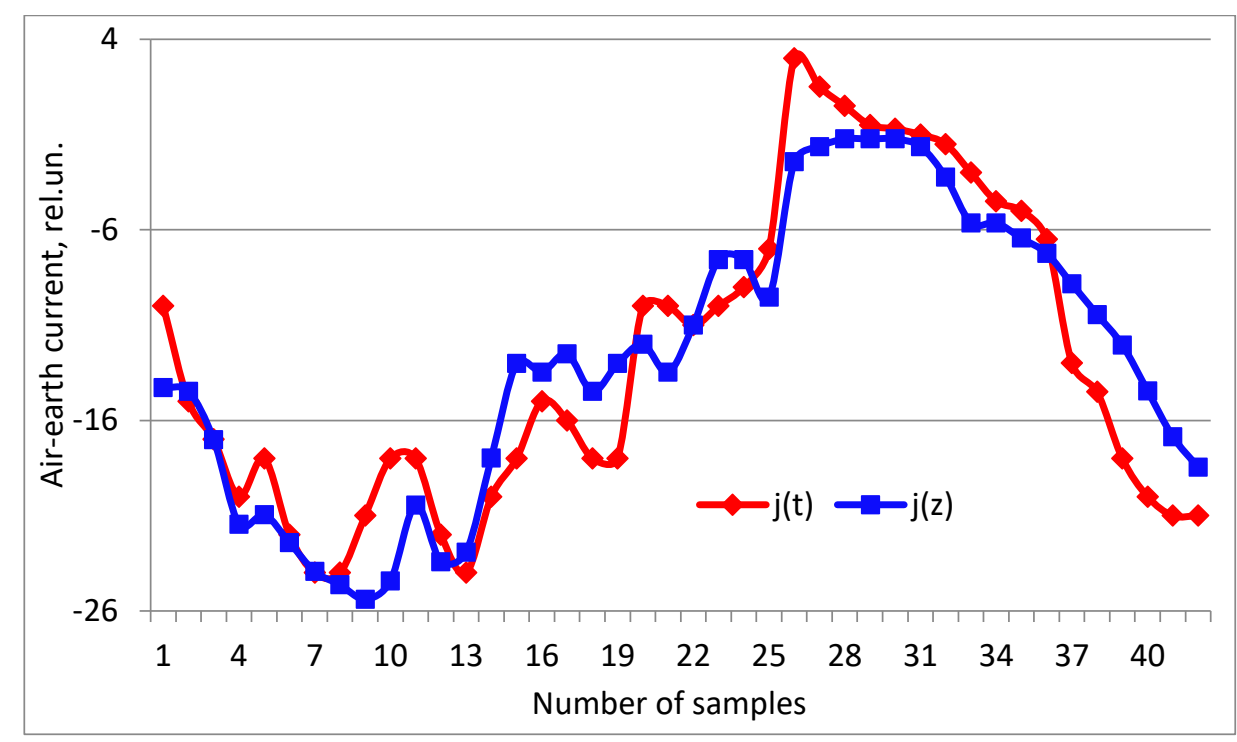

Fig. 5. The measured $j(t)$ and calculated $j(z)$ atmosphere-ground current values as a function of water level variations in the observation well $z$

In the first case, the increase in the water level before a thunderstorm was about $3 \mathrm{~mm}$; in case of a drizzle, variations in the level ranged from 0 to $3 \mathrm{~mm}$. The coefficient of correlation between measured and calculated values is $\mathrm{k}[\mathrm{j}(\mathrm{t}), \mathrm{j}(\mathrm{z})]=0.92$.

Similar relationships are observed between the measured values of the atmospheric electric field and the calculated values of the field as a function of the water level in the observation well, however, on two separate arrays, rather than on the whole data set - before a thunderstorm and during drizzle (Fig. 6).

The correlation coefficients between the measured and calculated curves are very large $\mathrm{k}=[\mathrm{E}(\mathrm{t}), \mathrm{E}(\mathrm{z})]_{\text {thunderstorm }}=0.98 ; \mathrm{k}=[\mathrm{E}(\mathrm{t}), \mathrm{E}(\mathrm{z})]_{\text {drizzle }}=0.91$. The result obtained is physically clear. The air-earth current is considered to be the most stable atmospheric electrical characteristic $[16,17]-\mathrm{j}=\mathrm{E}^{*} \lambda$, where $\lambda^{\Sigma}$ is the total polar conductivity of the air. In the pre-storm period, with no precipitation or with drizzling rain, polar conductivities, $\lambda$, were obviously different.

In the examples considered, growth of the ground-atmosphere air exchange is associated with the perch level rise (in spring, water was present at the site of instruments installation; water line in the nearby pond was about $0.8 \mathrm{~m}$ ).

When the aquifer level rises from the pore space of the surface soil layers, the soil air, which consists of hydrogen, methane, and radon, is squeezed to the atmosphere. Moreover, the process of the soil air motion in the pore space of covering rocks intensifies exhalation of the soil radon, as in the case of micro-oscillations of the ground. 


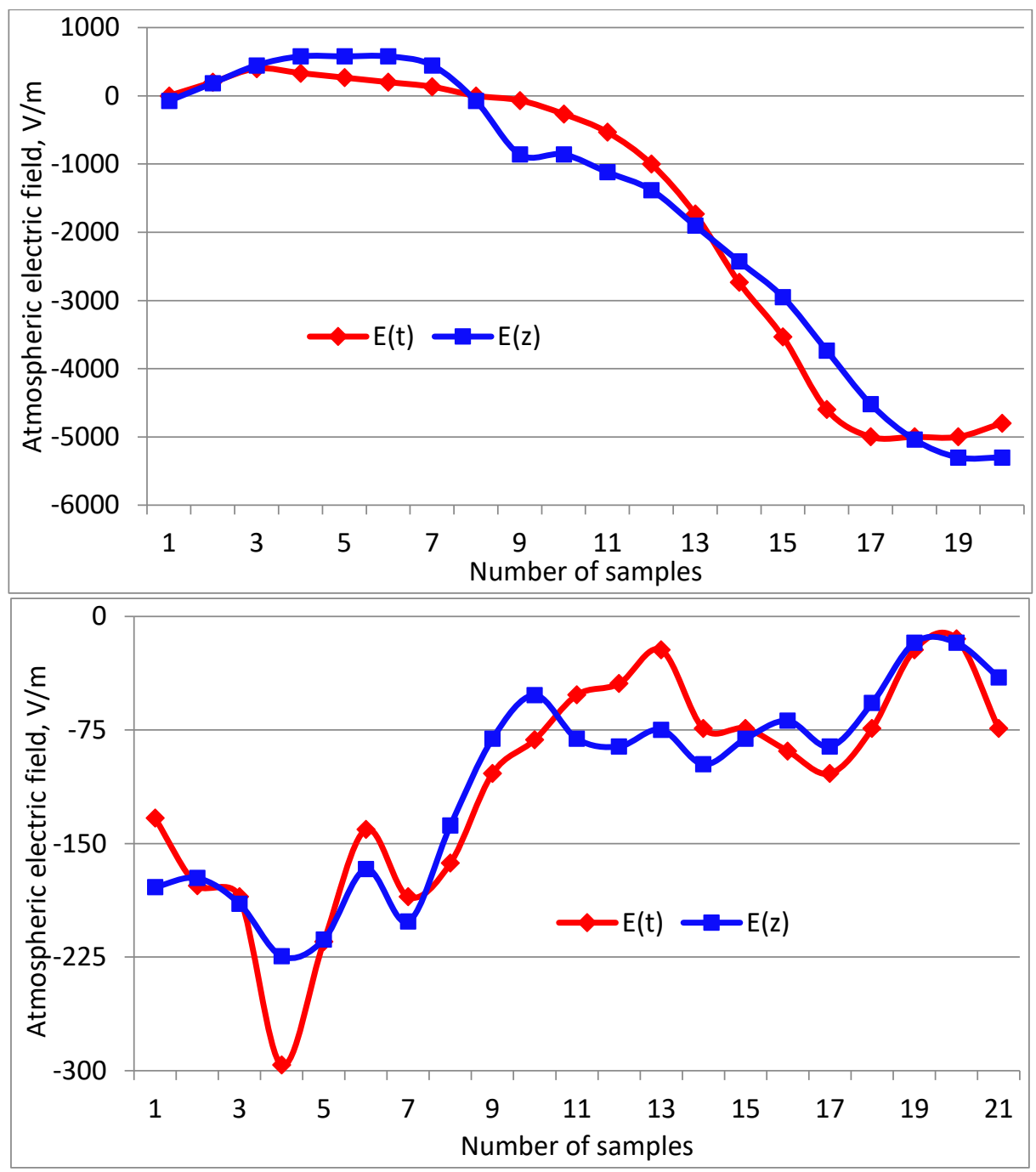

Fig. 6. Measured $E(t)$ and calculated $E(z)$ values of $A E F$, as a function of water level variations in the observation well $(z)$ before a thunderstorm and during drizzle

The exhaling soil radon is the interlink between water level dynamics and changes in electrical characteristics of the surface air with atmospheric pressure variations $[11,12]$. Let us consider experimental observation results for the radon soil and atmosphere volume activity at atmospheric pressure drop in the pre-storm period. The works were carried out on the territory of the Kasimov underground gas storage facility in the beginning of July 2003, where it was necessary to re-conduct observations of AEF, hydrogen and radon on 4 profiles with about 100 pickets. The works were supposed to be carried out in 3-4 days, but lasted for two weeks, because thunderstorms occurred over the studied area every 2 or 3 days. Measurements were carried out with a delay of 2 days after every thunderstorm. During this time, the near-surface 
layer of the soil dried out, and the tamponing moisture evaporated from the near-surface pore space.
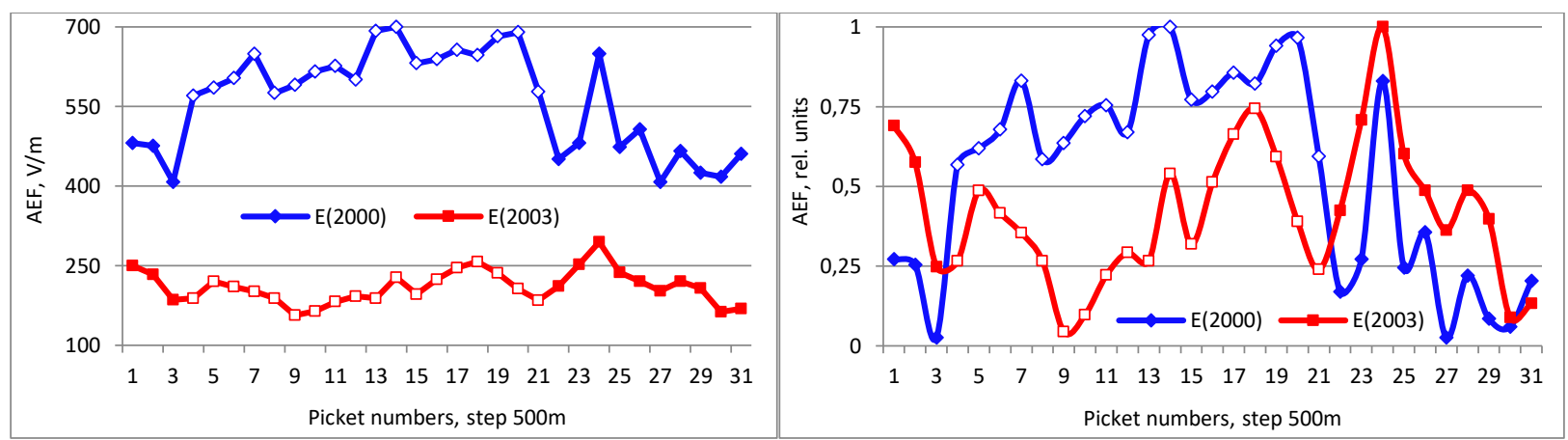

Fig. 7. The results of $A E F$ observations on the profile passing apart from the injection well cluster in 2000 and 2003; for clarity, the field measurement data are given in absolute and relative units

High values of the field on the profile recorded in 2000 - the average value of E (2000)ave $=563 \mathrm{~V} / \mathrm{m}-$ catch the eye. The reason for this is stretching of the pore space in the near-surface soil layers during the 3-month injection cycle and, naturally, excessive exhalation of the soil radon during this period. Upon completion of the injection cycle, the departure of combustible gas to the dome part of the gas storage facility, the geological environment returned to its original state, the pore space shrank. As a consequence of this shrinking, the ionizer exhalation decreases and the observed AEF values are high.

At the time of the beginning of measurements in 2003, the second month of injection of combustible gas was in progress. Injection is accompanied by stretching of rocks covering the reservoir, an increase in the pore space of the near-surface soil layers (during leveling at the Chervonopartizansk gas storage facility in Ukraine, a rise of the ground surface by $2 \mathrm{~cm}$ was recorded). An increase in the near-surface pore space volume will inevitably cause an intensification of the soil-atmosphere air exchange - the increased exhalation of soil radon, and a decrease in AEF.

The section of the controlled profile between pickets 6 and 14 fell towards the south of the injection well cluster, on the gas withdrawal line from the injection site to the dome part of the gas storage facility. The average field on the profile $\mathrm{E}(2003)_{\mathrm{ave}}=210 \mathrm{~V} / \mathrm{m}$; on the segment of pickets 6-14, even less than $\mathrm{E}(6-14)_{\mathrm{ave}}=190 \mathrm{~V} / \mathrm{m}$.

Unlike the North-Stavropol gas storage, which was arranged on the site of the NorthStavropol deposit [18], the storage reservoir near Kasimov was artificially selected. According to 
the observations made in 2009 , over the years of its operation, due to a not dense cover, the content of hydrogen and methane in the surface layers increased by almost 2 orders of magnitude. In particular, in 2009 , on the $6^{\text {th }}$ day after the completion of the weekly injection cycle at 19 injection wells, the average values of soil hydrogen and methane equaled $\mathrm{H}_{2}(\mathrm{ave})=$ 0.0012 vol. $\%, \mathrm{CH}_{4}($ ave $)=0.0220$ vol. $\%$; and on a profile $2 \mathrm{~km}$ away from the injection zone $\mathrm{H}_{2}$ (ave) $=0.00091$ vol. $\%, \mathrm{CH}_{4}($ ave $)=0.016$ vol.\% (data obtained from laboratory analysis of samples). The results of hydrogen and methane measurements suggested that the concentration of carrier gases in the near-surface layers of the soil was sufficient to ensure the increased radon exhalation, which caused relatively low AEF values.

Moreover, low AEF values on the profile indicate correct choice of the time delay for measurements after precipitation (see above). Hot weather, high humidity level associated with evaporation of moisture accumulated during thunderstorms would seem to have led to high values of the field [11] that was not observed. Fig. 8 illustrates the dependence of the air-ground current on the relative humidity. For clarity of current and relative humidity relationships, a 2day recording was chosen with a wide range of changes in relative humidity (data of measurements of relative humidity were taken at the nearest weather station located $30 \mathrm{~km}$ away from the current observation point).

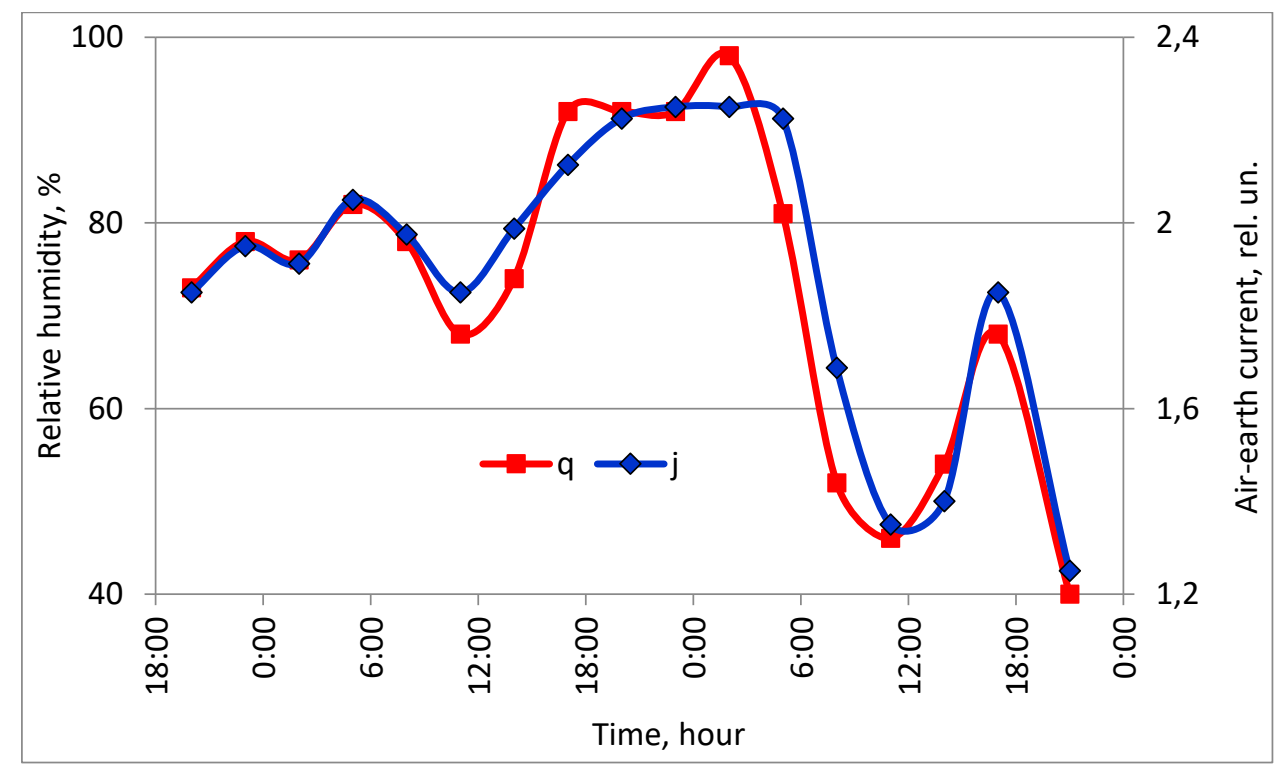

Fig. 8. Two-day record of variation of the vertical conduction current, j, and relative air humidity, q

The next observational profile, parallel to the first one, laid northward from the well cluster, at the edge of the reservoir projection on the ground surface. When working 
at the picket 6 of the profile passing through an open country, a cumulonimbus appeared on the horizon; during sampling at the picket 8 a thunderstorm began. Table 1 shows values of the soil radon $(\mathrm{Rn})$ and the atmospheric radon $[\mathrm{Rn}(\mathrm{a})]$ contents and AEF recorded at pickets 6 to 8 .

Time of operation on one picket and moving to the next picket took about 20 minutes: drilling of a sampling well, sampling, sample analysis for soil radon content, purging of the working volume by atmospheric air, atmospheric sample analysis for atmospheric radon content. When measuring the volumetric activity of soil radon and atmospheric radon, a single instrument was used. Changes in the monitored parameters were fast enough, and the results obtained might not be considered correct.

Table 1

Volumetric activity of soil radon, air radon and AEF, recorded at pickets № 6, 7, and 8

\begin{tabular}{|c|c|c|c|}
\hline Observation picket № & $\begin{array}{c}\mathrm{Rn}, \\
\mathrm{Bq} / \mathbf{l}\end{array}$ & $\begin{array}{c}\mathrm{Rn}(\mathrm{a}), \\
\mathrm{Bq} / \mathbf{l}\end{array}$ & $\begin{array}{c}\mathrm{AEF}, \\
\mathrm{V} / \mathrm{m}\end{array}$ \\
\hline 6 & 2.74 & 1.19 & 296 \\
\hline 7 & 4.73 & 3.66 & 394 \\
\hline 8 & 15.36 & 8.99 & -2.177 \\
\hline $\begin{array}{c}\text { Radon volumetric activity } \\
\text { increase }\end{array}$ & 5.6 times & 7.6 times & \\
\hline
\end{tabular}

The increase in radon volumetric activity during the pre-storm pressure drop was of obvious interest. Due to frequent thunderstorms in July 2003, the experiment was repeated, however, using two identical radon sensors that had been preliminarily checked for identity. The measurements were carried out in a stationary position, on a cushion of bulk soil (sand) $0.6-0.8 \mathrm{~m}$ thick, in a marsh area at a distance of hundreds of meters from the gas storage area. In a single sampling cycle, the soil air was pumped through the working volume of the hydrogen sensor to the working volume of the radon sensor. The measurements were carried out 43 minutes, 23 minutes, and 3 minutes prior to a thunderstorm begins. The measurement results are shown in Table 2; the last table row gives the relationship of the monitored parameters 3 minutes and 43 minutes prior to precipitation begins. 
Table 2

\section{Changes in volumetric activity of soil and atmospheric radon and AEF with the atmospheric pressure drop in the period prior to a thunderstorm}

\begin{tabular}{|c|c|c|c|c|}
\hline $\begin{array}{c}\text { Time before thunderstorm } \\
\text { (pressure drop time) }\end{array}$ & $\begin{array}{c}\mathbf{R n}, \\
\mathbf{B q} / \mathbf{I}\end{array}$ & $\begin{array}{c}\mathbf{R n}(\mathrm{a}), \\
\mathbf{B q} / \mathbf{I}\end{array}$ & $\begin{array}{c}\mathbf{H}_{\mathbf{2}}, \\
\mathbf{1 0}^{-4} \mathbf{v o l .} \%\end{array}$ & $\begin{array}{c}\mathrm{AEF}, \\
\mathbf{V} / \mathbf{m}\end{array}$ \\
\hline 43 minutes & 0.67 & 0.32 & 4.2 & 312 \\
\hline 23 minutes & 4.73 & 1.75 & 10.5 & -1.180 \\
\hline 3 minutes & 11.59 & 4.9 & 35.2 & -7.500 \\
\hline $\begin{array}{c}\text { Radon and hydrogen content } \\
\text { increase within 40 minutes }\end{array}$ & $\mathbf{1 7 . 3}$ times & $\mathbf{1 5 . 3}$ times & $\mathbf{8 . 3}$ times & \\
\hline
\end{tabular}

The increase in the volumetric activity of soil and atmospheric radon 40 minutes prior to the event is comparable with each other. The increase in soil hydrogen content is almost 2 times lower. As noted above, the contents of hydrogen and methane in the surface soil layers on the day 6 after completion of the weekly injection cycle are comparable, which is reasonably explained by the model representation of the gas parameter relationships. In addition to hydrogen and methane bubbles of a deep subvertical flow, radon is also transferred by methane, which content in the marshy area should be higher, Fig. 3. The results of measurements presented in Tables 1 and 2 suggest that in the area of the Kimovsk underground gas storage facility during the injection period, in the pre-storm period, the content of atmospheric radon may increase by 8-15 times.

For the 2-week period of work at the gas storage facility, only one night thunderstorm happened; the rest of the thunderstorms occurred in the afternoon - thermal thunderstorms. As the employees of the gas storage facility who lived 5-20 km from the place of work told, thunderstorms mainly occurred over the gas storage facility area. At home they had to water gardens in evenings.

Getting back to the results presented in the Section 2, «Geology and thunderstorm activity», it can be assumed that an excessive hydrogen and methane release to the atmosphere, which are radon gas carriers during the injection period and a pre-storm pressure drop, may be the reason for increased thunderstorm activity in July 2003 over the Kasimov underground gas storage area. 


\section{Conclusion}

In the mid-1900s in France, an idea of constrained radioactive ionization of air for obtaining the lighting conductor effect emerged. Radioactive lightning conductors were manufactured, although they were been produced for only a short time. The reason for the failure was the impossibility of safe use of a powerful ionizing radiation source. However, the ionizing effect, which can be achieved by a powerful point source, is achieved by a less powerful but aerial source. This is illustrated by an increase in thunderstorm activity in places where radionuclides are released as a result of the Chernobyl Accident. Within the framework of relationships between hydrogen, methane, radon, and surface atmospheric electricity elements, let us consider the effect of pre-storm atmospheric pressure drop on the surface air ionization.

In the system of relationships between gas and electric fields of the Earth and the atmosphere, only exhaling soil radon is directly related to the volume charge of the surface air; hydrogen and methane act only as the ionizer carrier gases to the atmosphere. The main part of the cloud-to-ground lightning discharges hits clayey, moist ground areas, gentle river banks and marshy lands, the area of equals to square kilometers. Close approach of groundwater to the surface is guaranteed by the presence of argillaceous confining beds with the parent matter content only 2-fold less than in granites. Marshy lands, in turn, indicate the presence of biogenic methane - the carrier gas for radon. In North America, thunderstorm activity occurs in the shale gas production areas; the main ingredient of the shale gas is methane. At the Kasimov underground gas storage, methane and hydrogen are ionizer carriers, and their concentration in the near-surface soil layers increases noticeably during injection. A pre-storm pressure drop can lead to an increase in the discharge of hydrogen, methane and radon by almost an order of magnitude, and the territories where this phenomenon is observed start working as aerial lightning conductors.

Formation of a cumulonimbus cloud is inevitably accompanied by a drop in atmospheric pressure. Moreover, about $60 \%$ of thunderstorms occurring throughout the year across the globe are thermal thunderstorms, the time range of which falls on the daily minimum of atmospheric pressure and the maximum of exhalation of soil radon.

Статья написана в рамках выполнения государственного задания (тема «Фундаментальный базис инноващионных технологий нефтяной $и$ газовой промыиленности (фундаментальные, поисковые и прикладные исследования)», № ААААA19-119013190038-2). 


\section{References}

1. Proceedings of the $3^{\text {rd }}$ All-Russian Symposium on Atmospheric Electricity. Tartu, 1986. 300 p. (In Russ.).

2. Proceedings of the of the $8^{\text {th }}$ Conference on Atmospheric Electricity. Uppsala, 1988. 897 p.

3. Proceedings of the $4^{\text {th }}$ All-Russian Symposium on Atmospheric Electricity. Nalchik: HMGI, 1990. 312 p. (In Russ.).

4. Proceedings of the $9^{\text {th }}$ Conference on Atmospheric Electricity. St. Petersburg, 1992. Vol. 1-3. 977 p.

5. Proceedings of the $5^{\text {th }}$ Russian Symposium on Atmospheric Electricity. Vladimir: VSU, 2003. 344 p. (In Russ.).

6. Proceedings of the $7^{\text {th }}$ All-Russian Conference on Atmospheric Electricity. St. Petersburg: Main Geophysical Observatory, 2012. 287 p. (In Russ.).

7. Imyanitov I.M., Shifrin K.S. Present state of research on atmospheric electricity // Soviet Physics Uspekhi. 1962. Vol. 2, No. 5 P. 292-322. https://doi.org/10.1070/ PU1962v005n02ABEH003413

8. The guide for surface observations over atmospheric electricity elements. Leningrad: Voeikov Main Geophysical Observatory, 1960. 95 p. (In Russ.).

9. Semenov K.A. Fair weather and atmospheric electricity elements // Proceedings of Voeikov Main Geophysical Observatory. 1982. No. 455. P. 112-119. (In Russ.).

10. Global Electrical Circuit: Proceedings of the All-Russian Conference. Yaroslavl, 2013. 136 p. (In Russ.).

11. Shuleikin V.N., Schukin G.G., Kupovyh G.V. Development methods and tools of applied geophysics - atmospheric-electrical monitoring of geological heterogeneity and geodynamic processes zones. St. Petersburg: RSHU, 2015. 205 p. (In Russ.).

12. Shuleikin V.N. Earth and atmospheric electricity. New York: Nova Science Publishers, 2018. 143 p.

13. Koshkin N.I., Shirkevich M.G. Handbook on elementary physics. Moscow: Nauka, 1972. 256 p. (In Russ.).

14. Bagmet A.L., Bagmet M.I., Barabanov V.L. et al. The study of the Earth tidal oscillations of the groundwater level in the Obninsk well // Izv. Akad. Nauk SSSR, Ser. Fizika Zemli. 1989. No. 11. P. 84-95. (In Russ.). 
15. Barabanov V.L., Grinevsky A.O., Kalachev A.A., Savin I.V. The well-aquifer system frequency response according to observations for groundwater level // Izv. Akad. Nauk SSSR, Ser. Fizika Zemli. 1988. No. 3. P. 41-50. (In Russ.).

16. Tverskoi P.N. A course in meteorology. Leningrad: Gidrometeoizdat, 1951. 887 p. (In Russ.).

17. Frenkel Ya.I. Theory of atmospheric electricity phenomena. Leningrad: State Publ. of Technical and Theoretical Literature, 1949. 155 p. (In Russ.).

18. Alekseev F.A., Voitov G.I., Lebedev V.S., Nesmelova Z.N. Methane. Moscow: Nedra, 1978. 310 p. (In Russ.). 


\title{
Грозозащита подземных газохранилищ
}

\author{
В.Н. Шулейкин \\ Институт проблем нефти и газа РАН, г. Москва \\ E-mail: shvn1947@yandex.ru
}

Аннотация. По мировой статистике гроз, молниевые разряды облако-земля чаще всего наблюдаются на глинистых и влажных участках, пологих речных берегах, заболоченных территориях, где грунтовые воды ближе всего подходят к поверхности земли. Здесь имеет место повышенный сброс в атмосферу радона и его газов-носителей - водорода и метана, который заметно усиливается при предгрозовом падении давления. Похожие условия создаются в период закачки на территориях кустов нагнетательных скважин искусственных газохранилищ, где существующие молниеотводы не способны гарантировать уверенную защиту от разрядов облакоземля.

Ключевые слова: водород, метан, радон, атмосферное давление, нагнетательные скважины, молниевые разряды.

Для цитирования: Шулейкин В.Н. Грозозащита подземных газохранилищ // Актуальные проблемы нефти и газа. 2019. Вып. 3(26). https://doi.org/10.29222/ipng.2078-5712.2019-26.art15

\section{Литература}

1. Труды III Всероссийского симпозиума по атмосферному электричеству. Тарту, 1986. $300 \mathrm{c}$.

2. Proceedings of the $8^{\text {th }}$ Conference on Atmospheric Electricity. Uppsala, 1988. 897 p.

3. Труды IV Всероссийского симпозиума по атмосферному электричеству. Нальчик: ВГИ, 1990. 312 с.

4. Proceedings of the $9^{\text {th }}$ Conference on Atmospheric Electricity. St. Petersburg, 1992. Vol. 1-3. 977 p.

5. Труды V Российской конференции по атмосферному электричеству. Владимир: ВГУ, 2003. 344 с.

6. Труды VII Всероссийской конференции по атмосферному электричеству. СПб: ГГО, 2012. $287 \mathrm{c}$.

7. Имянитов И.М., Шифрин К.С. Современное состояние исследований атмосферного электричества // Успехи физических наук. 1962. Т. 76, № 4. С. 593-642. https://10.3367/UFNr.0076.196204a.0593

8. Руководство по наземным наблюдениям за элементами атмосферного электричества. Л.: ГГО им. А.И. Воейкова, 1960. 95 с. 
9. Семенов К.A. Хорошая погода и элементы атмосферного электричества // Труды ГГО им. А.И. Воейкова. 1982. № 455. С. 112-119.

10. Глобальная электрическая цепь: Материалы Всероссийской конференции. Ярославль, 2013. 136 с.

11. Шулейкин В.Н., Щукин Г.Г., Куповых Г.В. Развитие методов и средств прикладной геофизики: Атмосферно-электрический мониторинг геологических неоднородностей и зон геодинамических процессов. СПб.: РГГМУ, 2015. 205 с.

12. Shuleikin V.N. Earth and atmospheric electricity // New York: Nova Science Publishers, 2018. 143 p.

13. Кошкин Н.И., Ширкевич М.Г. Справочник по элементарной физике. М.: Наука, 1972. $256 \mathrm{c}$.

14. Багмет А.Л., Багмет М.И., Барабанов В.Л. и др. Исследование земноприливных колебаний уровня подземных вод на скважине «Обнинск»// Известия АН СССР. Серия Физика Земли. 1989. № 11. С. 84-95.

15. Барабанов В.Л., Гриневский А.О., Калачев А.А., Савин И.В. Частотная характеристика системы скважина-водоносный горизонт по данным наблюдений за уровнем подземных вод // Известия АН СССР. Серия Физика земли. 1988. № 3. С. 41-50.

16. Тверской П.Н. Курс метеорологии. Л.: Гидрометеоиздат, 1951. 887 с.

17. Френкель Я.И. Теория явлений атмосферного электричества Л.: Гос. изд-во технико-теорет. лит., 1949. 155 с.

18. Алексеев Ф.А., Войтов Г.И., Лебедев В.С., Несмелова 3.Н. Метан. М.: Недра, $1978.310 \mathrm{c}$. 